\title{
The role of PET in monitoring therapy in fungal infections
}

\author{
Alfred O. Ankrah ${ }^{1,4}$, Hans C. Klein ${ }^{1,2}$, Lambert F.R. Span ${ }^{3}$, Erik F.J. de Vries ${ }^{1}$, \\ Rudi A.J.O. Dierckx ${ }^{1}$, Mike M. Sathekge ${ }^{4}$, Andor W.J.M. Glaudemans ${ }^{1}$
}

1. Department of Nuclear Medicine and Molecular Imaging, University of Groningen, University Medical Centre Groningen, Groningen, the Netherlands

2. Department of Psychiatry, University of Groningen, University Medical Centre Groningen, Groningen, the Netherlands

3. Department of Internal Medicine, Division of Hematology, University of Groningen, University Medical Centre Groningen, Groningen, the Netherlands

4. Department of Nuclear Medicine, University of Pretoria, South Africa

Corresponding author:

A.W.J.M. Glaudemans, MD, PhD

Nuclear Medicine Physician

University of Groningen

University Medical Center Groningen

Hanzeplein 1, PO 9700 RB, Groningen, the Netherlands

Tel: +31-50-3610146

E-mail: a.w.j.m.glaudemans@umcg.nl 


\begin{abstract}
Positron emission tomography (PET) is a powerful diagnostic nuclear medicine imaging technique. PET allows in vivo detection of a wide variety of physiologic and pathologic phenomena and it offers a noninvasive tool for the monitoring of therapy in various diseases. Invasive fungal infections (IFIs) are a global concern because of the increasing population of patients at risk of IFIs and the high morbidity and mortality. Therapy with antifungal agents is long-standing and expensive. The emerging resistant fungal strains make the management of IFls challenging. There is an absolute need for a sensitive noninvasive biomarker capable of monitoring the disease activity of IFIs and determining the efficacy of treatment at an early time point. PET imaging with ${ }^{18} \mathrm{~F}$ fluorodeoxyglucose (FDG) was used to detect and assess disease activity in IFI foci already over 20 years ago. At that time, it was suggested it could be a useful biomarker for monitoring anti-fungal therapy. However, this knowledge has still not been fully exploited for the management of IFIs. The literature reveals an increasing realization of the usefulness of PET in monitoring therapy of IFIs. In this review, we highlight the advantages of nuclear medicine techniques in the management of IFIs with emphasis of the role of PET in monitoring therapy efficacy.
\end{abstract}

\title{
Key words
}

Fungal infections; nuclear medicine; FDG PET; therapy monitoring; candida; aspergillus

\section{Introduction}

Nuclear medicine techniques are extensively used in the diagnosis and management of disease. Positron emission tomography (PET) and single photon emission computed tomography (SPECT) are the two main nuclear imaging techniques currently used in daily practice. Nuclear imaging, as a functional imaging technique, allows the visualization of physiochemical processes in the body of humans and animals. This allows the imaging of disease at the molecular level. Advances in medicine have resulted in an increased understanding of the molecular basis of diseases; therefore the use of nuclear medicine techniques is becoming more and more relevant in management of disease [1-3]. Despite advances in the diagnosis and management of invasive fungal infections (IFIs), the morbidity and mortality remains high [4]. This is partly due to the lack of sensitivity of the currently available microbiologic diagnostic and management platforms [4,5]. As a result of this inadequacy, new diagnostic and management tools are being developed and other therapeutic strategies are being explored [6-8]. There is an absolute need for a sensitive noninvasive biomarker to be able to monitor and evaluate the traditional and new methods of managing antifungal agents. Up until now, nuclear medicine has played a limited role in the management of IFIs. It has been over 2 decades ago since PET demonstrated the ability to not only detect fungal lesions but also to assess disease activity within these lesions [9]. These findings suggested that PET could be used to monitor IFIs. In spite of this, PET imaging has not been fully exploited in the management of IFIs in general and for the monitoring of therapy in IFIs in particular. In this review paper, we provide an overview of what 
nuclear medicine has to offer in patients with IFIs to hopefully make clear that there is an absolute role for PET in therapy evaluation and treatment decision-making.

\section{SPECT imaging in infections}

Several SPECT tracers have been used and are still being used in infection imaging. Labeled white blood cells (WBC) are still considered the gold standard for infection imaging [10,11], although the role of WBC imaging in patients with IFIs is not fully elucidated yet. The process of labeling is however laborious and technically demanding and there is a risk of contamination during handling blood products. The imaging process itself requires four hospital visits for the patient on two consecutive days [12]. A procedure that is not so laborious and technically demanding would be of great benefit to the patients, referring clinicians and nuclear medicine specialists. Other SPECT tracers such as gallium $67\left({ }^{67} \mathrm{Ga}\right)$ citrate were used in the past for infection; however, this tracer has largely been replaced by labeled WBC except in a few cases such as vertebral osteomyelitis $[13,14]$. There are several other SPECT tracers available for imaging microorganisms such as radiolabeled antibiotics, however these tracers are not being used in routine daily practice yet. In IFIs in particular, technetium $99 \mathrm{~m}\left({ }^{99 \mathrm{~m}} \mathrm{Tc}\right)$ fluconazole has been used and also molecules targeting other molecules or enzymes in the fungi (such as chitin, a component of the fungal cell wall) have been labeled with the aim to localize these infections [15-17], but also their use is still limited. However, these specific tracers for IFIs potentially could be used to monitor fungal infections and therefore deserve to be further explored.

\section{PET imaging in infection}

There are several PET tracers available in clinical use for infectious diseases that are able to reveal information at a molecular cell level. ${ }^{18} \mathrm{~F}$-fluorodeoxyglucose (FDG) is the most commonly used PET tracer in clinical setting. This glucose analogue is taken up by the glucose transporter (GLUT) on the surface of the cells in the body. Once it enters the cell it is phosphorylated by hexokinase into FDGphosphate, like glucose. However, unlike glucose, it is unable to continue further in the metabolic pathway and therefore remains trapped in the cell thereby allowing it to image the enhance glucose consumption in pathology [18]. The use of FDG in IFIs will be explained further on extensively. There are several other PET tracers available allowing us to image different physiological processes in infectious diseases. For example, ${ }^{68} \mathrm{Ga}$-DOTATATE is a somatostatin analogue used for imaging somatostatin receptors that are not only expressed by neuroendocrine tumors [19] but also in granulomatous diseases. ${ }^{68} \mathrm{Ga}$ citrate is an iron analogue that has already found some applications in infection and inflammation where its corresponding (SPECT) counterpart ${ }^{67} \mathrm{Ga}$ had a wellestablished role in the past [20]. However, ${ }^{18} \mathrm{~F}$-FDG PET is currently used for many roles in infection and inflammation for which ${ }^{67} \mathrm{Ga}$ was previously used. PET imaging, particularly with FDG, has been validated for monitoring several diseases [3, 21]. Its application has been very prominent in oncology for both hematological and solid tumors. Infectious and inflammatory diseases in which PET is currently used for therapy monitoring include inflammatory bowel disease, infected vascular grafts, endocarditis, and tuberculosis. Research or validation in larger prospective studies is under way in a lot of other diseases [21-25]. We will now focus on IFIs and provide an overview of what FDG PET has to offer in patients with IFIs with special focus on therapy evaluation and decision-making. The increased awareness of the role of PET imaging in invasive fungal infections (IFIs) has been well documented [26]. 


\section{Invasive fungal infections (IFIs)}

IFIs are a cause of high morbidity and mortality worldwide. Their contribution to the global burden of disease is largely unrecognized. Most are opportunistic infections. Although true mortality rates are unknown because of a lack of good epidemiological data, the incidence of invasive fungal infections is rising as a result of modern medical interventions and immunosuppressive diseases, such as AIDS. Despite the high mortality rates of invasive fungal infections, they remain understudied and underdiagnosed as compared with other infectious diseases [4, 27].

\section{Risk factors for IFIs}

Risk factors for IFIs include underlying disease such as hematologic or solid malignancies that cause immune suppression, Human Immunodeficiency syndrome (HIV), patients with end organ failure and diabetes mellitus. Medical therapies that cause immune suppression such as chemotherapy for hematologic or solid organ malignancies, hematopoietic stem cell transplantation, solid organ transplantation, invasive and complex surgeries, and immune modulating therapies are also risk factors for IFIs. Patients in intensive care units in whom indwelling catheters remain for a long period of time and in whom the prolonged use of antibiotics changes the gut flora are at risk for acquiring IFls. Patients with burns and premature babies are also at risk [30-32].

\section{Pathogens causing IFls}

IFIs are not caused by a single organism but by a number of different species of fungi that have been generally divided into yeasts and molds. Candida is the most common type of yeast whilst Aspergillus is the most common type of mold. Together these two fungi species constitute the most common fungi causing IFIs. There are a number of rarer causes of IFIs such as Zygomycosis, Histoplasmosis, Cryptococcus, Pneumocystis jeroveci amongst others, which can also cause IFIs [33, 34]. Some of these are more prevalent in certain population groups. Cryptococcus and Pneumocystis are more likely to be found in HIV patients. Indeed within the Candida species there are many subtypes such as Candida parapsilosis and Candida glabatra, which wary with geographic location, age of patient, and virulence. The morbidity and mortality varies with the type of fungus, the initial load at the site of infection and even the age of the patient. Furthermore, the length and depth of the immunosuppression state with or without swift adequate diagnostics importantly determines the outcome of IFIs.

\section{Candida}

This is the fourth most common blood stream infection in the US and the sixth most common in Europe [30,35]. The mortality rate of a Candida infection is $20-40 \%[6,36]$. Infants with invasive candidiasis who survive frequently have long-term neurological impairment, including cerebral palsy, blindness, hearing impairment, cognitive deficits, and periventricular leukomalacia [37]. The most predominant species is Candida albicans but there is a shift to the less common types like Candida glabatra. The susceptibility of the various species to antifungal agent varies [38].

Invasive Candidiasis may present as a candidemia with fever and sepsis. It may also present with a blood culture negative syndrome with disseminated (hepatosplenic) candidiasis or deep seated infections in distant organs in patients with hematologic cancer or other hematological disorders 
[30]. Monitoring therapy in the blood culture negative group is a challenging task and DG PET may have added value under such circumstances [39].

There are no prospective data available on the duration of treatment of invasive candidiasis. Recommendations are mainly based on expert opinions in both adults and children [40, 41]. A biomarker that can quantitatively assess disease activity in infectious foci would be of immense benefit in this regard.

\section{Aspergillus}

The mortality rate for an Aspergillus infection is reported to be over $50 \%-90 \%$, despite the use of antifungal agents [6,35]. Optimal duration of invasive aspergillosis therapy is not known [40]. Continuation of treatment for 6-12 weeks, or until immune recovery, or resolution of clinical/radiological evidence of disease, is most frequently recommended. The radiological evidence is based primarily on CT or MRI monitoring [42, 43]. The latter recommendation may end up exposing these patients to prolonged and unnecessary therapy and toxicity as there are well known cases in literature in where metabolic resolution of disease was objectified by FDG-PET with anatomical changes (by CT or MRI) lagging behind these metabolic changes (see also table 1).

Table 1 Published articles on the use of FDG PET in monitoring IFIs

\begin{tabular}{|c|c|c|c|c|c|c|}
\hline Cause of IFI & $\begin{array}{l}\text { Author } \\
\text { and year }\end{array}$ & Age & $\begin{array}{l}\text { Underlying } \\
\text { condition }\end{array}$ & Sex & Comment & $\begin{array}{l}\text { Finding on FDG } \\
\text { PET }\end{array}$ \\
\hline Aspergillus & $\begin{array}{l}\text { Franzius C } \\
\text { et al. } \\
2001 . \text { Clin } \\
\text { Nucl Med } \\
{[82]}\end{array}$ & $\begin{array}{l}3 \\
\text { months } \\
\text { (twins) }\end{array}$ & $\begin{array}{l}\text { Chronic } \\
\text { granulomatous } \\
\text { disease }\end{array}$ & $\mathrm{F}$ & $\begin{array}{l}\text { IFI was diagnosed } \\
\text { in an } \\
\text { asymptomatic } \\
\text { twin sibling of an } \\
\text { active case and } \\
\text { both cases } \\
\text { monitored by FDG } \\
\text { PET }\end{array}$ & $\begin{array}{l}\text { Resolution of } \\
\text { pulmonary FDG } \\
\text { uptake in both } \\
\text { infants after } \\
\text { antifungal } \\
\text { therapy }\end{array}$ \\
\hline Aspergillus & $\begin{array}{l}\text { Ozsahin H } \\
\text { et al. } \\
1998 . \\
\text { Blood [83] }\end{array}$ & 8 years & $\begin{array}{l}\text { Chronic } \\
\text { granulomatous } \\
\text { disease }\end{array}$ & $M$ & $\begin{array}{l}\text { The IFI was } \\
\text { unresponsive to } \\
\text { antifungal } \\
\text { therapy. FDG PET } \\
\text { used to monitor } \\
\text { and underwent } \\
\text { bone marrow } \\
\text { transplant (BMT) } \\
\text { successfully }\end{array}$ & $\begin{array}{l}\text { FDG avid } \\
\text { pulmonary } \\
\text { nodules } \\
\text { present before } \\
\text { (BMT) did not } \\
\text { worsen during } \\
\text { and after BMT }\end{array}$ \\
\hline Aspergillus & $\begin{array}{l}\text { Chamilos } \\
\text { G et al. } \\
\text { 2008. Med } \\
\text { Mycol [84] }\end{array}$ & 25 years & $\begin{array}{l}\text { Hodgkins } \\
\text { disease, HSCT }\end{array}$ & $M$ & $\begin{array}{l}\text { Pulmonary } \\
\text { nodules still } \\
\text { present on CT } \\
\text { after } 120 \text { days of } \\
\text { antifungal therapy }\end{array}$ & $\begin{array}{l}\text { FDG PET } \\
\text { activity in } \\
\text { nodules had } \\
\text { become } \\
\text { negative by day } \\
120\end{array}$ \\
\hline Aspergillus & $\begin{array}{l}\text { Chamilos } \\
\text { G et al. } \\
\text { 2008. Med } \\
\text { Mycol [84] }\end{array}$ & 39 years & $\begin{array}{l}\text { Non Hodgkins } \\
\text { lymphoma, } \\
\text { HSCT, GVHD }\end{array}$ & $M$ & $\begin{array}{l}\text { Scarring on CT in } \\
\text { IFI lesions after } \\
270 \text { days of } \\
\text { antifungal therapy }\end{array}$ & $\begin{array}{l}\text { FDG PET was } \\
\text { negative in } \\
\text { scarred tissue }\end{array}$ \\
\hline
\end{tabular}




\begin{tabular}{|c|c|c|c|c|c|c|}
\hline & & & & & & by day 270 \\
\hline Aspergillus & $\begin{array}{l}\text { Chamilos } \\
\text { G et al. } \\
\text { 2008. Med } \\
\text { Mycol [84] }\end{array}$ & 61 years & $\begin{array}{l}\text { Relapsed } \\
\text { esophageal } \\
\text { cancer }\end{array}$ & $M$ & $\begin{array}{l}\text { Monitor therapy } \\
\text { to determine } \\
\text { when to stop } \\
\text { antifungal agents }\end{array}$ & $\begin{array}{l}\text { PET positive on } \\
\text { day } 120 \text { but } \\
\text { negative on day } \\
320 \text { of } \\
\text { antifungal } \\
\text { treatment }\end{array}$ \\
\hline Aspergillus & $\begin{array}{l}\text { Hot el al. } \\
2011[85]\end{array}$ & 33 years & $\begin{array}{l}\text { Relapsing } \\
\text { Hodgkins diease, } \\
\text { HSCT }\end{array}$ & $M$ & $\begin{array}{l}\text { Monitor therapy } \\
\text { to determine } \\
\text { when to stop } \\
\text { antifungal agents }\end{array}$ & $\begin{array}{l}\text { Decrease in } \\
\text { FDG uptake on } \\
\text { follow up- } \\
\text { treatment } \\
\text { response }\end{array}$ \\
\hline Aspergillus & $\begin{array}{l}\text { Hot el al. } \\
\text { 2011. Clin } \\
\text { Microbiol } \\
\text { Infect [85] }\end{array}$ & 6 years & $\begin{array}{l}\text { Chronic } \\
\text { granulomatous } \\
\text { disease }\end{array}$ & $M$ & $\begin{array}{l}\text { Monitor therapy } \\
\text { to determine } \\
\text { when to stop } \\
\text { antifungal agents }\end{array}$ & $\begin{array}{l}\text { Persistence of } \\
\text { FDG uptake on } \\
\text { follow up }\end{array}$ \\
\hline Candida & $\begin{array}{l}\text { Xu B et al } \\
\text { 2010. Clin } \\
\text { Nucl Med } \\
{[86]}\end{array}$ & $\begin{array}{l}23 \\
\text { years }\end{array}$ & $\begin{array}{l}\text { Acute leukemia } \\
\text { (mixed lineage) }\end{array}$ & $M$ & $\begin{array}{l}\text { Led to change of } \\
\text { antifungal therapy } \\
\text { and helped } \\
\text { determine when } \\
\text { to stop antifungal }\end{array}$ & $\begin{array}{l}\text { Hepatic, splenic } \\
\text { and pelvic } \\
\text { uptake due to } \\
\text { IFI. Hepatic and } \\
\text { splenic lesions } \\
\text { progressed and } \\
\text { subsequently } \\
\text { resolved after } \\
\text { antifungal } \\
\text { therapy change }\end{array}$ \\
\hline Candida & $\begin{array}{l}\text { Xu B et al } \\
2010 . \text { Clin } \\
\text { Nucl Med } \\
{[86]}\end{array}$ & $\begin{array}{l}57 \\
\text { years }\end{array}$ & $\begin{array}{l}\text { Acute } \\
\text { myeoloblastic } \\
\text { leukemia }\end{array}$ & $M$ & $\begin{array}{l}\text { Detected poor } \\
\text { response to } \\
\text { antifungal therapy } \\
\text { and led to change } \\
\text { in antifungal }\end{array}$ & $\begin{array}{l}\text { Pulmonary and } \\
\text { hepatic uptake } \\
\text { due to IFI which } \\
\text { progressed and } \\
\text { eventually } \\
\text { normalized } \\
\text { after antifungal } \\
\text { therapy change }\end{array}$ \\
\hline Candida & $\begin{array}{l}\text { Xu B et al } \\
2010 . \text { Clin } \\
\text { Nucl Med } \\
{[86]}\end{array}$ & $\begin{array}{l}30 \\
\text { years }\end{array}$ & $\begin{array}{l}\text { Acute } \\
\text { myeoloblastic } \\
\text { leukemia }\end{array}$ & $\mathrm{F}$ & $\begin{array}{l}\text { Detected poor } \\
\text { response to } \\
\text { antifungal therapy } \\
\text { and led to change } \\
\text { in antifungal }\end{array}$ & $\begin{array}{l}\text { Hepatic uptake } \\
\text { duet o IFI } \\
\text { worsened and } \\
\text { resolved after } \\
\text { switch in } \\
\text { antifungal } \\
\text { therapy }\end{array}$ \\
\hline Candida & $\begin{array}{l}\text { Avet J Jr et } \\
\text { al. } 2009 . \\
\text { Eur J Nucl } \\
\text { Med Mol }\end{array}$ & $\begin{array}{l}16 \\
\text { years }\end{array}$ & Leukemia & - & $\begin{array}{l}\text { Detected poor } \\
\text { response to } \\
\text { antifungal therapy } \\
\text { and led to change }\end{array}$ & $\begin{array}{l}\text { Multiple liver, } \\
\text { spleen, kidney, } \\
\text { muscle, } \\
\text { myocadial and }\end{array}$ \\
\hline
\end{tabular}




\begin{tabular}{|c|c|c|c|c|c|c|}
\hline & $\begin{array}{l}\text { Imaging } \\
{[87]}\end{array}$ & & & & in antifungal & $\begin{array}{l}\text { pulmonary } \\
\text { uptake due to } \\
\text { IFI which } \\
\text { resolved on } \\
\text { switching } \\
\text { antifungal }\end{array}$ \\
\hline Candida & $\begin{array}{l}\text { Wallner M } \\
\text { et al. } \\
\text { 2013. Herz } \\
\text { [88] }\end{array}$ & $\begin{array}{l}72 \\
\text { years }\end{array}$ & $\begin{array}{l}\text { Bioprosthetic } \\
\text { Aortic } \\
\text { Valve }\end{array}$ & $M$ & $\begin{array}{l}\text { Showed good } \\
\text { response to } \\
\text { antifungal therapy }\end{array}$ & $\begin{array}{l}\text { Complete } \\
\text { resolution of } \\
\text { increased FDG } \\
\text { uptake in the } \\
\text { area of } \\
\text { prosthetic } \\
\text { aortic valve }\end{array}$ \\
\hline Candida & $\begin{array}{l}\text { Teyton P } \\
\text { et al. } \\
\text { 2009. Clin } \\
\text { Nucl Med } \\
\text { [89] }\end{array}$ & $\begin{array}{l}22 \\
\text { years }\end{array}$ & $\begin{array}{l}\text { Acute myeoloid } \\
\text { leukemia }\end{array}$ & $M$ & $\begin{array}{l}\text { Detected poor } \\
\text { response to } \\
\text { antifungal therapy } \\
\text { and led to change } \\
\text { in antifungal }\end{array}$ & $\begin{array}{l}\text { Multiple uptake } \\
\text { in liver and } \\
\text { spleen not } \\
\text { responding to } \\
\text { antifungal } \\
\text { therapy which } \\
\text { resolved after a } \\
\text { switch in } \\
\text { antifungal } \\
\text { therapy }\end{array}$ \\
\hline Candida & $\begin{array}{l}\text { Hot el al. } \\
\text { 2011. Clin } \\
\text { Microbiol } \\
\text { Infect [85] }\end{array}$ & 27 years & $\begin{array}{l}\text { Testicular } \\
\text { Cancer }\end{array}$ & $M$ & $\begin{array}{l}\text { Decrease in FDG } \\
\text { uptake on follow } \\
\text { up- treatment } \\
\text { response }\end{array}$ & $\begin{array}{l}\text { FDG uptake in } \\
\text { spleen } \\
\text { decrease after } \\
\text { antitherapy } \\
\text { administered }\end{array}$ \\
\hline Candida & $\begin{array}{l}\text { Hot el al. } \\
\text { 2011. Clin } \\
\text { Microbiol } \\
\text { Infect [85] }\end{array}$ & 24 years & $\begin{array}{l}\text { Hodgkins } \\
\text { disease, HSCT, } \\
\text { GVHD }\end{array}$ & $M$ & $\begin{array}{l}\text { Used to monitor } \\
\text { antifungal therapy }\end{array}$ & $\begin{array}{l}\text { Persistence of } \\
\text { FDG uptake } \\
\text { after } 9 \text { months } \\
\text { of antifungal } \\
\text { therapy }\end{array}$ \\
\hline Zygomycosis & $\begin{array}{l}\text { Ritz N et } \\
\text { al. } 2015 . \\
\text { Eur J } \\
\text { Pediatr } \\
\text { [90] }\end{array}$ & $\begin{array}{l}9 \\
\text { years }\end{array}$ & $\begin{array}{l}\text { Burkitts } \\
\text { Iympoma }\end{array}$ & $\mathrm{F}$ & $\begin{array}{l}\text { Showed } \\
\text { extrapulmonary } \\
\text { disease and } \\
\text { directed biopsy } \\
\text { and allowed } \\
\text { follow up of } \\
\text { antifungal therapy }\end{array}$ & $\begin{array}{l}\text { Gradual } \\
\text { resolution of } \\
\text { pulmonary } \\
\text { uptake and } \\
\text { therapy } \\
\text { switched } \\
\text { because of } \\
\text { unresolving } \\
\text { splenomegaly }\end{array}$ \\
\hline Zygomycosis & $\begin{array}{l}\text { Altini C et } \\
\text { al. } 2015 . \\
\text { Clin Nucl }\end{array}$ & $\begin{array}{l}13 \\
\text { years }\end{array}$ & $\begin{array}{l}\text { Acute } \\
\text { Lymphoblastic } \\
\text { leukemia }\end{array}$ & $\mathrm{F}$ & $\begin{array}{l}\text { Assessed } \\
\text { response to } \\
\text { therapy and }\end{array}$ & $\begin{array}{l}\text { FDG uptake in } \\
\text { the rhino- }\end{array}$ \\
\hline
\end{tabular}




\begin{tabular}{|c|c|c|c|c|c|c|}
\hline & Med [91] & & & & $\begin{array}{l}\text { correctly } \\
\text { predicted } \\
\text { progression when } \\
\text { MRI did not }\end{array}$ & $\begin{array}{l}\text { orbital-cerebral } \\
\text { area which } \\
\text { became more } \\
\text { intense }\end{array}$ \\
\hline Zygomycosis & $\begin{array}{l}\text { Liu Y et al. } \\
\text { 2013. Clin } \\
\text { Nucl Med } \\
{[92]}\end{array}$ & $\begin{array}{l}23 \\
\text { years }\end{array}$ & Aplastic anemia & $\mathrm{F}$ & $\begin{array}{l}\text { Serial scan } \\
\text { enabled } \\
\text { modification of } \\
\text { antifungal therapy }\end{array}$ & $\begin{array}{l}\text { FDG uptake in } \\
\text { head and neck } \\
\text { duet o IFI } \\
\text { gradually } \\
\text { resolved }\end{array}$ \\
\hline Zygomycosis & $\begin{array}{l}\text { Chamilos } \\
\text { G et al. } \\
\text { 2008. Med } \\
\text { Mycol [84] }\end{array}$ & 59 years & $\begin{array}{l}\text { Relapsed CLL, } \\
\text { HSCT, GVHD }\end{array}$ & $M$ & $\begin{array}{l}\text { Persistence of } \\
\text { mass after } 60 \\
\text { days of antifungal } \\
\text { therapy }\end{array}$ & $\begin{array}{l}\text { Complete } \\
\text { resolution of } \\
\text { FDG uptake in } \\
\text { pulmoary IFI } \\
\text { after } 60 \text { days of } \\
\text { antifugal } \\
\text { therapy }\end{array}$ \\
\hline Zygomycosis & $\begin{array}{l}\text { Chamilos } \\
\text { G et al. } \\
\text { 2008. Med } \\
\text { Mycol [84] }\end{array}$ & 42 years & $\begin{array}{l}\text { Relapsed CLL, } \\
\text { HSCT, GVHD }\end{array}$ & $M$ & $\begin{array}{l}\text { Concordant } \\
\text { response of } C T \\
\text { and PET findings- } \\
\text { resolution }\end{array}$ & $\begin{array}{l}\text { Minimal uptake } \\
\text { in regressing } \\
\text { pulmonary } \\
\text { nodules on CT } \\
90 \text { days after } \\
\text { antifungal } \\
\text { thrapy }\end{array}$ \\
\hline $\begin{array}{l}\text { Unidentified } \\
\text { yeast-like fungi }\end{array}$ & $\begin{array}{l}\text { Miyazaki Y } \\
\text { et al. } \\
\text { 2011. Ann } \\
\text { Hematol } \\
\text { [93] }\end{array}$ & $\begin{array}{l}32 \\
\text { years }\end{array}$ & $\begin{array}{l}\text { Relapsed acute } \\
\text { myeloid } \\
\text { leukemia, BMT }\end{array}$ & $\mathrm{F}$ & $\begin{array}{l}\text { Detected } \\
\text { response to } \\
\text { antifungal therapy } \\
\text { earlier than other } \\
\text { imaging } \\
\text { modalities } \\
\text { enabling timely } \\
\text { BMT to be } \\
\text { undertaken with } \\
\text { no recurrence of } \\
\text { IFI after BMT }\end{array}$ & $\begin{array}{l}\text { FDG uptake in } \\
\text { liver lesions } \\
\text { due to IFI had } \\
\text { diminished at a } \\
\text { time when the } \\
\text { was little } \\
\text { change in other } \\
\text { imaging } \\
\text { modalities }\end{array}$ \\
\hline Histoplasma & $\begin{array}{l}\text { Kasaliwal } \\
\text { R et al } \\
2014 \text {. Clin } \\
\text { Nucl Med } \\
{[94]}\end{array}$ & $\begin{array}{l}60 \\
\text { years }\end{array}$ & None & $\mathrm{F}$ & $\begin{array}{l}\text { Monitoring of } \\
\text { antifungal therapy } \\
\text { was consistent } \\
\text { with clinical } \\
\text { outcome }\end{array}$ & $\begin{array}{l}\text { Reduction in } \\
\text { FDG uptake in } \\
\text { mediastinal } \\
\text { nodes and } \\
\text { adrenal glands } \\
\text { bilaterally }\end{array}$ \\
\hline Histoplasma & $\begin{array}{l}\text { Tsai YJ et } \\
\text { al. } 2013 \\
\text { Clin } \\
\text { Imaging } \\
\text { [95] }\end{array}$ & 74 years & Diabetes mellitus & $M$ & $\begin{array}{l}\text { Monitoring of } \\
\text { antifungal therapy } \\
\text { was consistent } \\
\text { with clinical } \\
\text { outcome }\end{array}$ & $\begin{array}{l}\text { Reduction in } \\
\text { FDG uptake in } \\
\text { adrenal glands } \\
\text { bilaterally }\end{array}$ \\
\hline Coccidiomycosis & $\begin{array}{l}\text { Hot el al. } \\
\text { 2011. [85] }\end{array}$ & 61 years & None & $\mathrm{F}$ & $\begin{array}{l}\text { FDG PET showed } \\
\text { treatment }\end{array}$ & $\begin{array}{l}\text { Decreased FDG } \\
\text { uptake in lung }\end{array}$ \\
\hline
\end{tabular}




\begin{tabular}{|c|c|c|c|c|c|c|}
\hline & & & & & response & $\begin{array}{l}\text { and } \\
\text { mediastinum } \\
\text { after antifungal } \\
\text { therapy }\end{array}$ \\
\hline Mycetoma & $\begin{array}{l}\text { Hot el al. } \\
\text { 2011. Clin } \\
\text { Microbiol } \\
\text { Infect [85] }\end{array}$ & 42 years & None & $M$ & $\begin{array}{l}\text { Showed favorable } \\
\text { response to } \\
\text { antifungal agents }\end{array}$ & $\begin{array}{l}\text { Decreased FDG } \\
\text { uptake in the } \\
\text { lower limb and } \\
\text { fibula affer } \\
\text { therapy }\end{array}$ \\
\hline Phomopsis & $\begin{array}{l}\text { Hot el al. } \\
\text { 2011. Clin } \\
\text { Microbiol } \\
\text { Infect [85] }\end{array}$ & 59 years & Diabetes mellitus & $M$ & $\begin{array}{l}\text { Showed favorable } \\
\text { response to } \\
\text { antifungal agents }\end{array}$ & $\begin{array}{l}\text { Decreased FDG } \\
\text { uptake in the } \\
\text { right ankle affer } \\
\text { therapy }\end{array}$ \\
\hline Scedosporium & $\begin{array}{l}\text { Hot el al. } \\
\text { 2011. Clin } \\
\text { Microbiol } \\
\text { Infect [85] }\end{array}$ & 32 years & $\begin{array}{l}\text { Cystic fibrosis, } \\
\text { chronic liver } \\
\text { disease }\end{array}$ & $M$ & $\begin{array}{l}\text { Used to monitor } \\
\text { antifungal therapy } \\
\text { in vertebral } \\
\text { osreomyelytis }\end{array}$ & $\begin{array}{l}\text { FDG uptake } \\
\text { revealed more } \\
\text { vertebral } \\
\text { involment than } \\
\text { MRI that } \\
\text { persisted on } \\
\text { follow up }\end{array}$ \\
\hline Cryptococcus & $\begin{array}{l}\text { Dubbioso } \\
\text { R et al. } \\
\text { 2013. J } \\
\text { Neurol Sci } \\
{[96]}\end{array}$ & $\begin{array}{l}63 \\
\text { years }\end{array}$ & None & $\mathrm{F}$ & $\begin{array}{l}\text { Monitored } \\
\text { therapy in the } \\
\text { choroid plexus }\end{array}$ & $\begin{array}{l}\text { Reduction in } \\
\text { uptake in the } \\
\text { medial } \\
\text { temporal } \\
\text { cortex which } \\
\text { corresponded } \\
\text { to the choroid } \\
\text { plexus on co- } \\
\text { registered } \\
\text { images }\end{array}$ \\
\hline
\end{tabular}

\section{Other species}

Morbidity and mortality amongst other species varies with the type. In Cryptococcus, which is a very common IFI in HIV patients, the mortality is $20-70 \%[6,44]$. The duration of therapy for most of the rarer causes of IFls is either based on expert opinion or in some cases unclear. In some cases, treatment lasted more than 2 years, thereby exposing the patient to toxicity and drug-drug interactions that frequently accompany antifungal agents [40-46].

\section{Diagnosis of IFls}

FDG PET is a sensitive functional imaging technique that detects pathology before anatomical changes occur. In IFIs it detects the glucose uptake in the inflammatory cells that are attracted to the site of infection and are activated. This change precedes anatomical changes and so occurs before 
imaging methods that rely on anatomical changes will become positive. FDG PET would thus pick up metastatic infective foci at a time when other imaging modalities would be negative. This is important in early diagnosis of IFls that impacts on the survival the host. Nowadays, hybrid camera systems (PET/CT) exist, leading to better localization of the metabolically active infectious focus and to better diagnostic accuracy.

The detection of metastatic foci in different sites of the body would influence the management of the IFI. The selection of the optimum therapy must take into account the location of IFIs. FDG PET imaging offers this advantage. The antifungal agent penetrates different tissues to a different extent. Cases of IFIs where there is improvement in many sites, but persistent disease activity in a particular site are known to occur (for an example see figure 2). If one monitors treatment efficacy with an imaging procedure limited to one region of the body other potentially persistent locations may be missed and therapy management may be inadequate.

\section{PET imaging in invasive fungal infections}

For about 2 decades, IFIs have been known to accumulate FDG [9]. The FDG uptake in these focal lesions was found to correspond to disease activity, making FDG PET a potential candidate for monitoring IFIs. The first publications about IFIs and FDG were focused on the poor specificity of FDG PET, because IFIs were found to cause a false positive uptake in the diagnosis of cancer in patients [47-49]. Only later the potential role of FDG PET in the diagnosis of IFIs was recognized. These publications concentrated on the ability of FDG PET to stage IFIs and highlighted the ability of FDG PET to detect occult foci of IFIs [50,51]. Recently publications on the topic however have been predominated by FDG's ability to monitor therapy in IFIs, which will be discussed later on.

\section{Other diagnostic possibilities}

Identification of the offending fungus with subsequent drug susceptibility testing remains the gold standard in diagnosing IFIs. However as a result of the increased mortality associated with the long turn over times other indirect methods of diagnosing have been employed. These include serological markers such as galactomannan assays for Aspergillus, nucleic acid techniques and radiological imaging particularly with high resolution CT scan of the chest. However the definitive diagnosis of IFIs still remains a challenge; it needs biopsy with morphology of invasiveness of the fungus besides culturing. Robust and more sensitive diagnostics are still required $[4,27,52]$.

\section{Management of IFIs}

The administration of an antifungal drug after the definitive microbiological proof of a fungal infection constitutes what has been defined as targeted antifungal therapy. There is a long turnaround time for culture results with late microbiological documentation in the course of infections [52-55]. A delay in therapy institution in IFIs is associated with increased mortality [56-59]. As a result, different antifungal strategies have been studied for preventing IFIs in non-neutropenic critically ill patients. The administration of any antifungal drug prior to the definitive microbiological evidence of fungal infection constitutes an untargeted antifungal treatment. Recently, the European Society of Clinical Microbiology and Infectious Diseases (ESCMID) provided the definitions of three different treatment strategies, classifying them into prophylactic, pre-emptive and empiric 
treatments [60]. Prophylaxis has been defined as the administration of antifungal agents in patients without proven or suspected IFIs (i.e. absence of microbiological or radiological evidence) but with risk factors for its development. Pre-emptive treatment (diagnosis-driven approach) has been defined as treatment triggered by imaging with (probable IFI) or without (possible IFI) microbiological evidence of fungal infection, without definitive microbiological proof. Surrogate biomarkers for the presence of fungal infection (e.g. 1-3 ß-D-glucan, mannan/anti-mannan antibody) have been investigated for this purpose [61,62]. Empiric treatment (fever-driven approach) has been defined as the antifungal treatment triggered by signs and symptoms of infection in patients at risk for IFI, in the absence of microbiological and imaging evidence of infection at the moment of therapy institution. A recent review of the data provided evidence that the role of untargeted therapy is still not conclusive in non-neutropenic patients [52]. PET imaging, by virtue of the ability to quantify uptake, would be a helpful tool for the early diagnosis in pre-emptive strategies but more importantly it offers objective quantifiable measures of response to therapy in IFIs.

\section{Classes of antifungal drugs available}

The classes of antifungals currently in clinical uses for IFIs include the fluoropyrimidines, polyenes, azoles, and the echinocandins [63].

Fluoropyrimidine a synthetic analogue of DNA, has only 5-fluorocytosine as the antifungal agent in use. It is a prodrug possessing no antifungal properties on its own but converted to 5-fluorouracil (the antitumor agent) by a cytosine deaminase enzyme present in fungi and not in humans by which it exerts its antifungal effects. It diffuses rapidly throughout the body after oral administration and is generally safe although it may cause hepatotoxicity and bone marrow suppression. It has broadspectrum activity particularly potent with Candida and other yeasts though its action against Aspergillus and other molds are more limited. Its use is declining due to development of resistance and it is mostly used in combination with other antifungal agents [64, 65].

Polyenes are amphiphilic organic compounds known as macrolides that target ergosterol, the main sterol component of fungal membranes. Amphotericin B belongs to this class. It has a broad spectrum covering most fungi. They possess an affinity for human cholesterol giving rise to their toxicity. The toxicity is mainly hepatic and renal and liposomal or lipid complexes minimize these side effects. Resistance has been reported but is a rare clinical event. The major limitation of the use of this drug is its toxicity [66].

Azoles are the most commonly used antifungal drugs in clinical practice and include fluconazole, itraconazole and the more recent new generation of triazoles: voriconazole and posaconazole. The target is a key enzyme in the ergosterol biosynthethic. The azoles, particularly fluconazole, have a broad spectrum of activity though resistance to emerging fungal infections has been reported. Fluconazole has both oral and intravenous formulations and diffuses throughout the body, even to the cerebrospinal fluid. The azoles have specific drug interactions, particularly to some antineoplastic and HIV drugs. Resistance of candida species against fluconazole has developed due to over-prescription for prophylaxis and treatment. The newer generation triazoles have a wide range of activity and are more effective against Candida and Aspergillus. The side effects and drug interactions are similar to older azoles, but at a greater extent as higher antifungal plasma levels can 
be reached. There is also cross-resistance to the newer generation azole in fungi resistant to classical azoles [67-69].

Echinocandins, a new class in the antifungal agents, inhibit enzymes responsible for the synthesis of the cell wall. They include micafungin, caspofungin, and anidulafungin. They possess low toxicity and interaction with other drugs is rare. They have a broad activity range active against both Candida and Aspergillus. There are however some fungi that show resistance or intermediate susceptibility. The other limitation of these drugs is the absence of an oral formulation. They are particularly useful when other antifungal agents are ineffective. Each drug in this class has special advantages such as the ability to use anidulafungin in patients with hepatic and renal impairment. Their combination with other antifungal agents has a synergistic or at least an additive effect [70-72].

\section{Other strategies to combat fungal infections}

In addition to the antifungal agents described above, a number of other therapeutic approaches are employed or being considered to combat fungal infections. The concept of "repurposing" where established medication to treat new diseases has emerged as an approach to expedite drug development in general. In fungal infections, the immune modulator calcenerium and the target of rapamycin inhibitors possess antifungal activity and synergize fluconazole. Antineoplastic and antidepressant agents have been shown to be potential drugs for repurposing in the management of IFIs. Many of these drugs have antifungal activity themselves but also potentiate the action of the traditional antifungal agents [6, 73-75].

The susceptibility to the outcome of IFIs depends on the pathogen and the host. The traditional antifungal agents deal with the pathogen, (the fungus). The efficacy of the immune response and the degree of the immune suppression in the patient are the major host determinants. Modifying the host is a target in the management of IFIs. Strategies to modify the host include cytokine therapy, granulocyte transfusion, antibodies, vaccinations, natural killer cell treatments and adoptive $T$ cell transfer. These strategies are already in use or being explored for the management of IFIs [7, 76-81].

Non pharmacologic therapy such as surgical debridement of infected vertebrae or endoscopic drainage of lung abscesses may also be necessary in addition to antifungal agents for the management of IFIs. Surgery is warranted in cases of zygomycosis.

All these procedures, both pharmacological and nonpharmacological, require monitoring by a sensitive biomarker and PET, as a noninvasive functional imaging modality, has the potential to do so.

\section{Monitoring therapy in IFIs}

Despite advances in diagnosis and management IFIs still remain a cause of high morbidity and mortality in immunocompromised patients [4]. This is because the standard diagnostic modalities lack the sensitivity for detection and therapeutic monitoring of IFIs [5, 27,28]. This is of global concern because there is an expanding population of patients at risk for IFIs particularly in the past three decades. The reason for this increase is the advance in medical therapy exposing patient to more immunosuppressed states and complex surgical procedures patients are exposed to [4]. 


\section{Monitoring IFIs with FDG PET}

The available literature shows that FDG PET is avid irrespective of the pathogen causing the IFI. This provides a sensitive early staging of the IFI and a noninvasive means to follow up the therapy of the patient. The disease activity at various different sites of the body can be adequately evaluated. It can also tell at an early point in the therapy if a particular therapy is not adequate and therefore a modification of antifungal therapy or even a non-pharmacologic therapy such as surgical treatment may be required.

There are relatively few publications on the use of FDG PET for monitoring therapy response in IFIs and these are usually only case reports. Large multicenter studies are lacking. Earlier case reports focused the IFIs as a cause of false positive results in cancer diagnosis, because the scans were primarily performed to evaluate patients with a suspected malignancy. There has been a shift in focus and as a result recent articles on FDG and IFIs more and more address monitoring therapy (table 1). The available publications demonstrate the usefulness of FDG in monitoring both the more common causes of IFIs, Candida and Aspergillus sp. [82-88], and also the other causes of IFIs such as Zygomycosis sp. [84, 90-92], Histoplasmosis sp [94, 95], Coccidimycosis, Phomopsis, Mycetomas spp. [85] and Crytococcus sp. [96]. In one report, FDGPET/CT correctly predicted disease progression in IFIs, while MRI erroneously predicted an improvement in disease [91]. These reports included both patients with typical risk factors of immune suppression and those without the typical risk factors. An overview of all the available literature on the use of FDG PET in monitoring IFIs is presented in Table 1.

Again although underrepresented, the literature shows monitoring therapy is effective in children just as well as in adults $[82,83,85,87]$. High resolution CT scan was found to have an impact on the early diagnosis of IFIs, especially in Aspergillus, resulting in including this technique in the guidelines. It has been documented however that there are differences in CT findings between children and adults [97]. The findings of FDG uptake in both the adult and pediatric population suggest it can be used as a tool in both population groups.

FDG imaging led to a change in antifungal therapy because of the poor response seen on follow up FDG studies in a number of reports $[86,87,89]$. It also helped to extend antifungal therapy in a case in which response was seen but in which there was still some disease activity after 120 days. After another 200 days of antifungal therapy the scan became negative for active disease. FDG PET was also helpful in informing the clinician when to stop antifungal therapy by showing inactive disease at a time point when other imaging modalities had not completely resolved [84].

In another study, FDG was unfortunately not performed before starting the therapy but when the scan was performed during therapy, it not only showed poor response to the antifungal treatment but it also revealed other foci of infection that were previously unknown to the clinicians [87].

In IFIs FDG is taken up by activated inflammatory cells. Some concerns have been raised about the ability of FDG PET to detect IFIs in neutropenic patient that may be the case in patients with hematologic malignancies. Studies conducted in patients with febrile neutropenia showed that infections, including IFIs, were clearly identified. The mechanism is probably due to uptake by other inflammatory cells such as macrophages and not neutrophils, or due to a stress response of the infected host cells $[97,98]$. 


\section{Our experience in monitoring IFIs with FDG PET}

In our hospital, we now already use FDG PET for therapy evaluation in patients with IFIs for a couple of years and in our experience FDG PET helped in decision making in most patients. For example, FDG PET allowed the modification of therapy in one child and in another child with hepatic aspergillosis it helped in deciding to perform surgery for final resolution of all the hepatic lesions. This child showed improvement in all hepatic lesions, except one that had a large necrotic center and became larger during therapy (figure 1). The decision was taken to go to surgery for this progressive lesion and indeed large necrotic areas were found and an encapsulation, the reason why the antifungal drugs were not effective there.
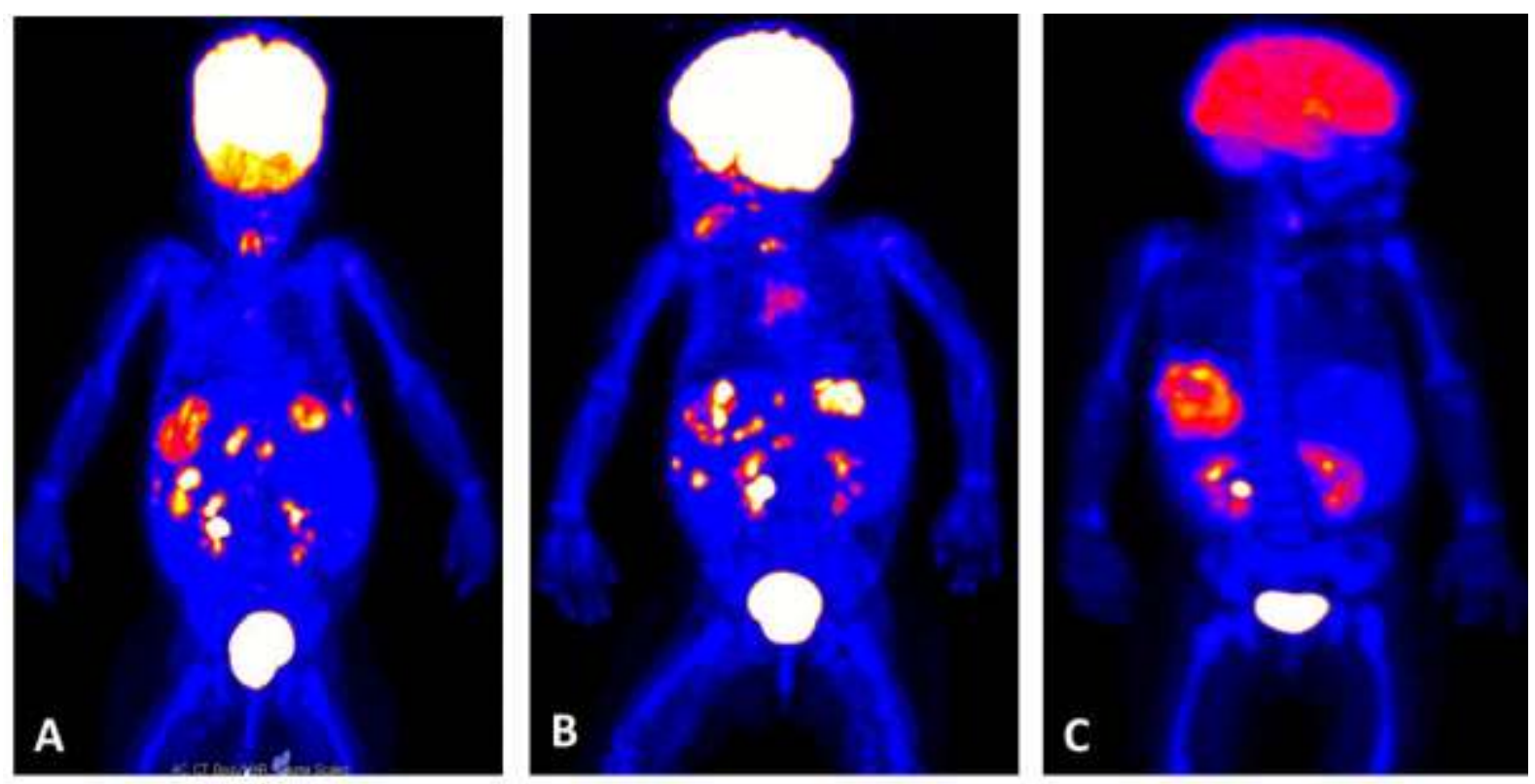

Figure 1: Example of use of FDG-PET in therapy monitoring in a 2-year old girl with Langerhans cell histiocytosis and bone marrow transplantation. She was diagnosed (after biopsy) with aspergillus lesions in the liver.

(A) Baseline FDG-PET scan, MIP image, revealing multiple fungal lesions in the liver.

(B) FDG-PET scan after 6 months of antifungal therapy, showing a decrease in FDG uptake of some liver lesions, but an increase in other liver lesions. Based on these findings, antifungal treatment was switched.

(C) FDG-PET scan after therapy switch, revealing disappearance of all liver lesions expect one which became larger in time. Eventually this lesion was surgically removed, showing an encapsulated fungal lesion, which could not be reached by the antifungal drugs. Note also the decreased uptake in the brain at the third scan. This scan was performed under sedation.

Figure 2 shows an adult patient with disseminated candidiasis in which treatment had to be modified and changed to totally ensure that underlying infection had been eliminated. This is very important when an immunosuppressive therapy such as hematologic stem cell transplant or chemotherapy is being planned. 


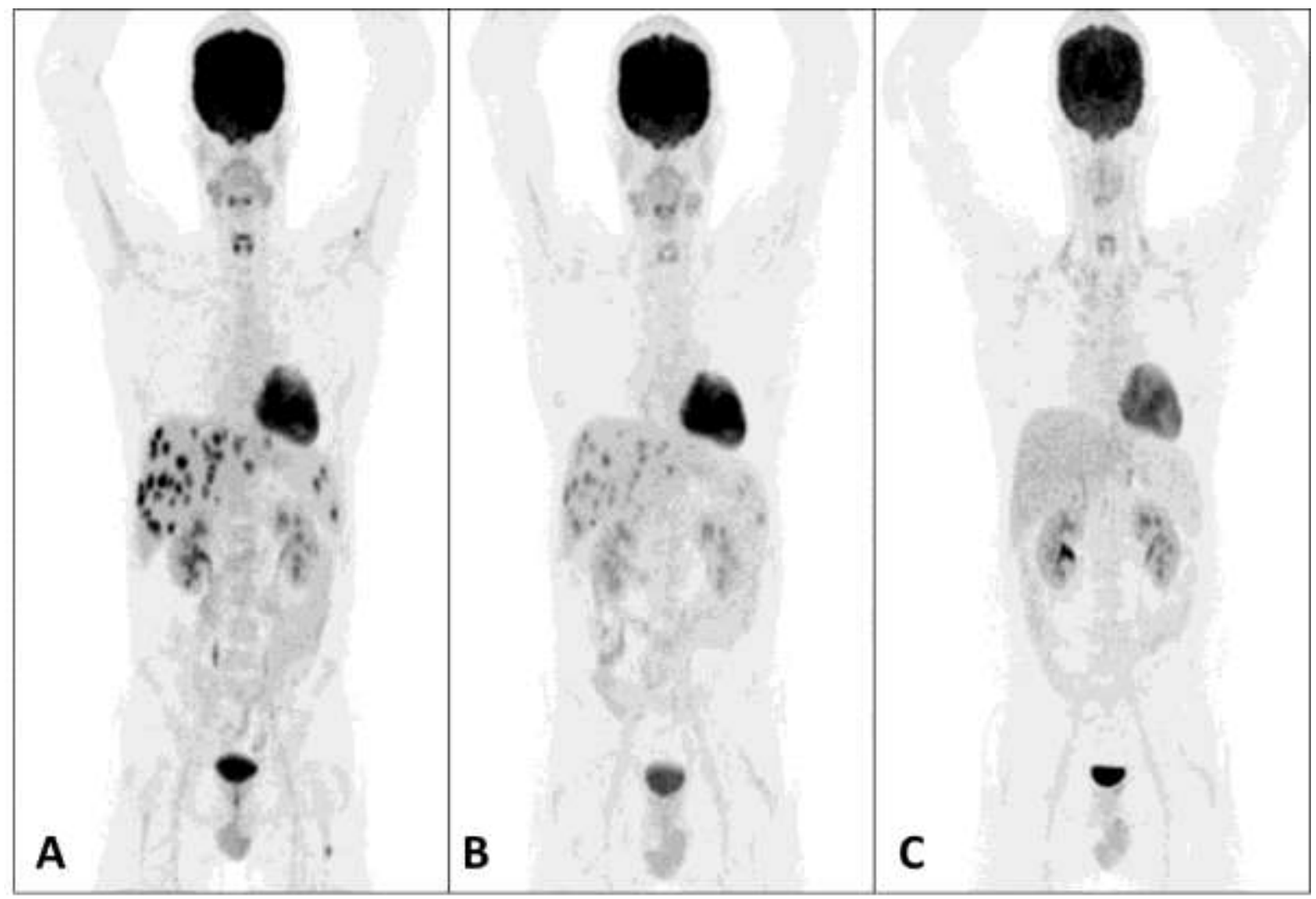

Figure 2 Example of use of FDG-PET in therapy monitoring in a 24-year old male on treatment for ALL. He was diagnosed with candidiasis by a biopsy.

(A) Baseline FDG-PET scan, MIP image, revealing multiple fungal lesions in the liver and spleen.

(B) FDG-PET scan, MIP image, after 4 months of antifungal therapy, showing a decrease in FDG uptake in some liver lesions (partial response). Based on these findings, antifungal treatment was switched.

(C) FDG-PET scan, MIP image, 3 weeks after therapy switch, revealing disappearance of almost all hepatic and splenic lesions.

In figure 3 another example of the added value of FDG PET in monitoring IFIs is shown. This is a 42year old female in remission after treatment for acute myeloid leukemia. She was diagnosed with aspergillus by a combination of clinical presentation, serological markers and a high resolution CT scan of the chest. The initial FDG PET scan was performed to assess the activity and stage infection. The serial scans showed a gradual decrease of FDG uptake till there was complete metabolic response. After this complete response, the chemotherapy could be continued. 

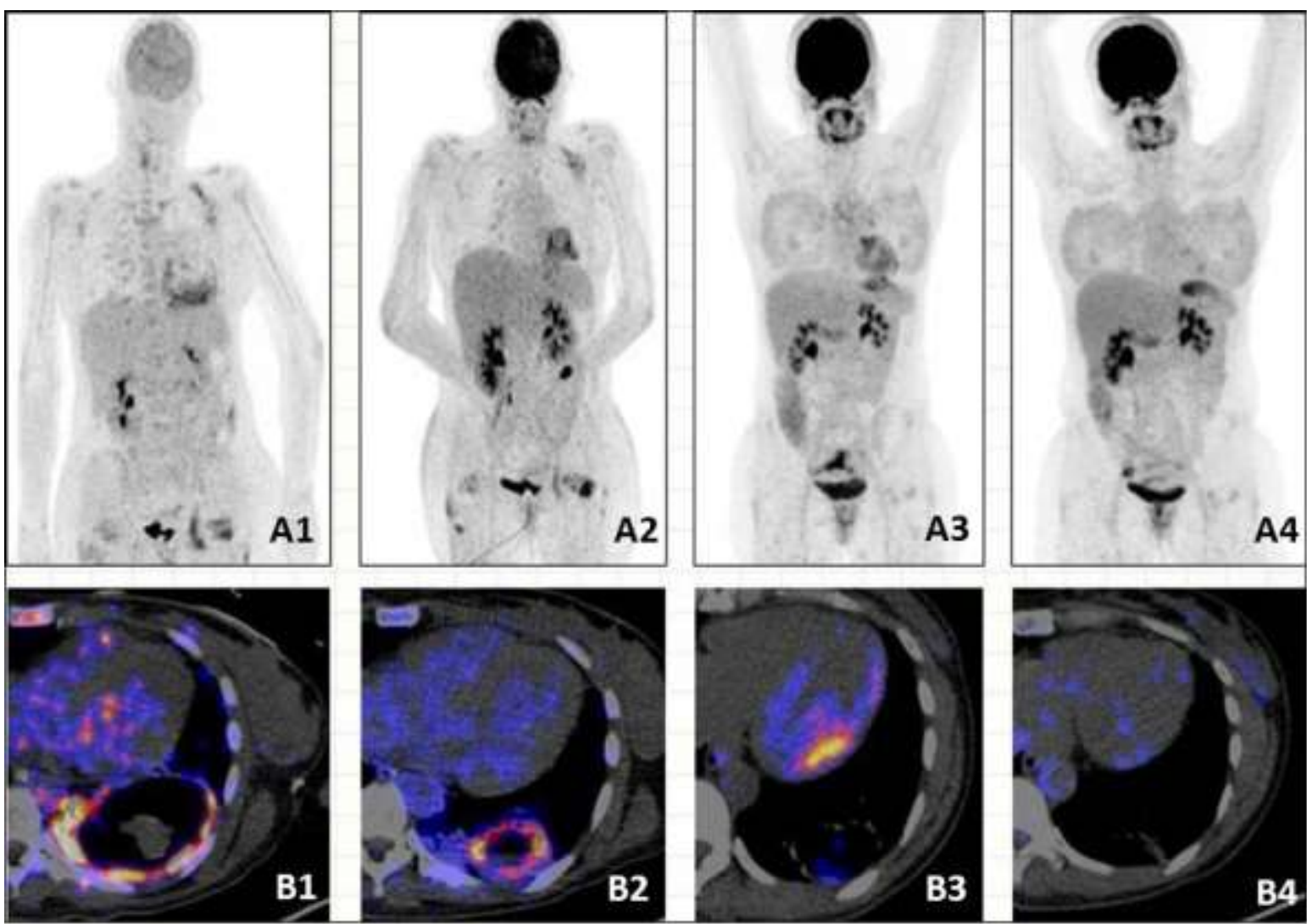

Figure 3: Example of the use of FDG-PET/CT in therapy monitoring in a 42-year old female in remission after treatment for AML. She was diagnosed with aspergillus by a combination of clinical presentation, serological markers and a high resolution CT scan of the chest. The initial FDG PET scan was done assess the activity and stage infection.

(A1) Baseline FDG-PET scan, MIP image and (B1) corresponding fused PET/CT transverse section through a single large pulmonary lesion with increased glucose metabolism and a cold area in the center consistent with active aspergillosis.

(A2-A4) Other 3 FDG-PET scans, MIP image and (B2-B4) corresponding transverse fusion images: follow up scans while patient was on treatment showing good response and after the $3^{\text {rd }}$ follow up scan antifungal therapy was stopped and patient was able to undergo a new cycle of chemotherapy.

\section{Therapeutic drug monitoring of antifungal agents}

Some antifungal agents exhibit marked variability in bloodstream concentrations that are difficult to predict on the basis of dosing alone. Therapeutic drug monitoring (TDM) by measuring plasma levels is advocated by some experts and guidelines as an adjunct in routine administration of some antifungal agents [99-101]. TDM may increase the probability of a successful outcome, prevent drugrelated toxicity and potentially prevent the emergence of antifungal drug resistance. Much of the evidence that supports TDM is circumstantial [99].

TDM assesses the availability in plasma, thereby monitoring the pharmacokinetics; it does not address the antifungal activity in vivo. FDG PET can provide insight in the total disease activity in the body. The combination of TDM in situations where it is warranted and FDG PET imaging will provide 
not only pharmacokinetic information about the drug but would enable visualization of the fungicidal effect and may help to determine if there is resistance to antifungal therapy.

\section{Limitations}

The use of FDG PET imaging in IFIs is not without challenges. FDG PET imaging uses ionizing radiation, which lead to radiation burden to the patient. When FDG PET is combined with contrast enhanced $\mathrm{CT}$ the radiation burden is even higher. When diagnostic CT scans are performed the CT component may contribute as much as $81 \%$ to combined radiation dose [102]. Multiple studies for follow up would mean an even further increase in the radiation burden. The risk of a devastating and life-threatening outcome of an IFI exceeds in most cases the disadvantages of the radiation exposure used in FDG PET/CT imaging. The principle of "as low as possible achievable (ALARA)" is adhered to during FDG PET/CT imaging to avoid unnecessary radiation to the patient. To reduce the radiation burden we recommend a baseline scan with a diagnostic contrast enhanced CT and all follow up studies with a low dose CT. As PET/MRI becomes more available we would recommend its use, especially in children and in cases where soft tissue definition would be beneficial.

Secondarily, FDG has sites of high physiological uptake in areas such as the brain, urinary tract and heart that may make visualization of IFI foci in these organs difficult. In spite of this FDG visualized IFIs in the brain and was used to follow up IFI in this area [96]. The physiologic uptake may pose difficulties in determining if there is complete metabolic response when FDG is used for monitoring therapy and disease activity is reducing.

\section{Conclusion and future perspectives}

There is an increasing evidence on the use of FDG PET imaging to monitor IFIs. It has been shown, mainly in case reports, to be useful across a wide range of different fungal species. It can have a large impact on management resulting in modification or switch in antifungal treatment. It is especially important in monitoring therapy of blood culture negative IFIs with suspected foci of infection in organs of patients with hematologic malignancies or solid organ transplant. It may also help to determine when antifungal agents may not effectively reach the site and surgery rather than antifungal therapy alone should be recommended. Large multicenter prospective studies are needed to enable this technique to be incorporated into major guidelines.

FDG PET is unable to discriminate fungal infection from other infections such as bacterial infections or malignancy. The clinical setting in which disease occurs but more importantly histopathological finding is needed for definitive diagnosis. The search for other radiopharmaceuticals to give more specific answers to specific problem is an ongoing process. Molecular imaging may provide clinicians with unlimited possibilities and in the future may enable the use of personalized medicine when PET imaging probes are developed that are able to target the specific fungi causing IFIs.

${ }^{99 \mathrm{~m}} \mathrm{Tc}$ - fluconazole was successful in imaging Candida infections. ${ }^{99 \mathrm{~m}} \mathrm{Tc}$-fluconazole accumulated only in viable Candida infections and its uptake correlated very well with the number of fungi present, suggesting it could be useful for monitoring antifungal therapy. It did not accumulate in bacteria of Aspergillus fumigates. The corresponding PET radiotracer ${ }^{18} \mathrm{~F}$-Fluconazole has not been so successful in imaging Candida infections. There is poor accumulation at infected sites and the amount of background activity in the liver decreases its sensitivity to detect Candida infections. The reason for 
the difference between this PET tracer and its SPECT equivalent may be the different labeling methods resulting in ${ }^{18} \mathrm{~F}$-fluconazole being much more lipophilic than ${ }^{99 \mathrm{~m}} \mathrm{Tc}$-fluconazole, resulting in poorer imaging characteristics [15-17]. If the synthesis of a labeled fluconazole analog for PET imaging is optimized, it may provide a radiolabeled probe specific for Candida.

Again, in preclinical PET imaging studies, ${ }^{68} \mathrm{Ga}$ citrate labeled with Triacetylfusarinine C (TAFC) and ferrioxamine $E$ (FOXE) have been shown to be highly sensitive for imaging Aspergillus. TAFC and FOXE are common trihydroxamate-type siderophores with relatively low molecular weight produced by fungi, bacteria, and some plants for scavenging iron to make it available to the organism. These tracers appear to be specific for the imaging of Aspergillus. Radiotracers that are based on detection of antigens present in fungi but not present in mammals may also provide valuable probe for imaging and monitoring response of antifungal therapy [26].

A new probe for noninvasive detection of Aspergillus fumigatus lung infection based on antibodyguided positron emission and magnetic resonane imaging has recently been developed. This $\left[{ }^{64} \mathrm{Cu}\right]$ DOTA labeled $\mathrm{A}$. fumigatus-specific monoclonal antibody demonstrated the ability to distinguish invasive pulmonary aspergillosis to bacterial infections in mice. This could potentially be a very useful and specific monitor invasive pulmonary aspergillosis [103].

In summary, PET imaging has the potential to become a sensitive, noninvasive tool to monitor fungal infections in adults and children treated with both pharmacologic and nonpharmacologic therapeutic strategies. The role of PET may even become more important in the future with the development of new specific tracers.

\section{Compliance with ethical standards}

Disclosure statement: All authors have nothing to disclose.

Conflicts of interest: None of the authors have a conflict of interest.

Ethical approval: All procedures performed in this study were in accordance with the ethical standards of the institutional research committee and the national regulations and also with the principles of the 1964 Declaration of Helsinki and its later amendments as far as they are required for this type of review study.

\section{References}

1. Signore A, Glaudemans AWJM. The molecular approach to image infections and inflammations by Nuclear Medicine techniques. Ann Nucl Med. 2011;25:681-700.

2. Jensen MM, Kjaer A. Monitoring of anti-cancer treatment with (18)F-FDG and (18)F-FLT PET: a comprehensive review of pre-clinical studies. Am J Nucl Med Mol Imaging. 2015 Oct 12;5(5):431-56.

3. Zhu A, Lee $D$, Shim $\mathrm{H}$. Metabolic positron emission tomography imaging in cancer detection and therapy response. Semin Oncol. 2011;38(1):55-69.

4. Brown GD, Denning DW, Levitz SM. Tackling human fungal infections. Science. 2012; 336(6082):647.

5. Salvatore CM, Chen TK, Toussi SS, DeLaMora P, Petraitiene R, Finkelman MA, Walsh TJ. $(1 \rightarrow 3)-\beta-d-$-Glucan in Cerebrospinal Fluid as a Biomarker for Candida and Aspergillus 
Infections of the Central Nervous System in Pediatric Patients. J Pediatric Infect Dis Soc. 2015; pii: piv014.

6. Butts A, Krysan DJ. Antifungal Drug Discovery: Something Old and Something. New PLoS Pathog. 2012; 8(9): e1002870.

7. Ravikumar S, Win MS, Chai LY. Optimizing Outcomes in Immunocompromised Hosts: Understanding the Role of Immunotherapy in Invasive Fungal Diseases. Front Microbiol. 2015;6:1322.

8. Pfaller MA1,2, Wolk DM3, Lowery TJ. T2MR and T2Candida: novel technology for the rapid diagnosis of candidemia and invasive candidiasis. Future Microbiol. 2016;11:103-17.

9. Ichiya $Y$, Kuwabara $Y$, Sasaki M, Yoshida T, Akashi $Y$, Murayama $S$ et al. FDG-PET in infectious lesions: The detection and assessment of lesion activity. Ann Nuc Med. 1996;10(2):185-91.

10. Glaudemans AW, de Vries EF, Vermeulen LE, Slart RH, Dierckx RA, Signore A. A large retrospective single-centre study to define the best image acquisition protocols and interpretation criteria for white blood cell scintigraphy with ${ }^{99} \mathrm{mTc}-\mathrm{HMPAO}-$ labelled leucocytes in musculoskeletal infections. Eur J Nucl Med Mol Imaging. 2013;40(11):1760-9.

11. Glaudemans AW, Signore A.FDG-PET/CT in infections: the imaging method of choice? Eur J Nucl Med Mol Imaging. 2010;37(10):1986-91.

12. Vaidyanathan S, Patel CN, Scarsbrook AF, Chowdhury FU.FDG PET/CT in infection and inflammation--current and emerging clinical applications. Clin Radiol. 2015;70(7):787-800.

13. Tumeh SS, Belville JS, Pugatch R, McNeil BJ. Ga-67 scintigraphy and computed tomography in the diagnosis of pneumocystis carinii pneumonia in patients with AIDS. A prospective comparison. Clin Nucl Med. 1992;17(5):387-94

14. Tzen KY, Yen TC, Lin KJ. Value of Ga-67 SPECT in monitoring the effects of therapy in invasive aspergillosis of the sphenoid sinus. Clin Nucl Med. 1999;24(12):938-41.

15. Lupetti A, de Boer MG, Erba P, Campa M, Nibbering PH. Radiotracers for fungal infection imaging. Med Mycol. 2011;49 Suppl 1:S62-9.

16. Siaens R, Eijsink VG, Vaaje-Kolstad G, Vandenbulcke K, Cornelissen B, Cuvelier C, Dierckx R, Slegers $G$. Synthesis and evaluation of a $99 m$ Technetium labeled chitin-binding protein as potential specific radioligand for the detection of fungal infections in mice. Q J Nucl Med Mol Imaging . 2006;50(3):155-66.

17. Siaens R, Eijsink VG, Dierckx R, Slegers G. [123]I-Labeled chitinase as specific radioligand for in vivo detection of fungal infections in mice. J Nucl Med. 2004;45(7):1209-16.

18. Pauwels EK, Ribeiro MJ, Stoot JH, McCready VR, Bourguignon M, Mazière B. FDG accumulation and tumor biology. Nucl Med Biol. 1998;25(4):317-22.

19. Skoura E, Michopoulou S, Mohmaduvesh M, Panagiotidis E, Al Harbi M, et al. The Impact of 68Ga-DOTATATE PET/CT Imaging on Management of Patients with Neuroendocrine Tumors: Experience from a National Referral Center in the United Kingdom. J Nucl Med. 2016;57(1):34-40.

20. Vaidyanathan S, Patel CN, Scarsbrook AF, Chowdhury FU. FDG PET/CT in infection and inflammation--current and emerging clinical applications. Clin Radiol. 2015 Jul;70(7):787-800.

21. Glaudemans AW, de Vries EF, Galli F, Dierckx RA, Slart RH, Signore A. The use (18)F-FDG$\mathrm{PET} / \mathrm{CT}$ for diagnosis and treatment monitoring of inflammatory and infectious diseases. Clin Dev Immunol. 2013;2013:623036. 
22. Kuwaki K, Mitsuyama K, Kaida H, Takedatsu H, Yoshioka S, Yamasaki H, et al. A longitudinal study of FDG-PET in Crohn disease patients receiving granulocyte/monocyte apheresis therapy. Cytotherapy. 2015; pii: S1465-3249(15)01104-4.

23. Metser U, Lo G. FDG-PET/CT in abdominal post-transplant lymphoproliferative disease. $\mathrm{Br} \mathrm{J}$ Radiol. 2016;89(1057):20150844.

24. Hu N, Tan Y, Cheng Z, Hao Z, Wang Y. FDG PET/CT in Monitoring Antituberculosis Therapy in Patient With Widespread Skeletal Tuberculosis. Clin Nucl Med. 2015 Nov;40(11):919-21.

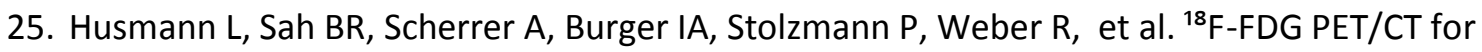
Therapy Control in Vascular Graft Infections: A First Feasibility Study. J Nucl Med. 2015;56(7):1024-9.

26. Haas $\mathrm{H}$, Petrik M, Decristoforo $\mathrm{C}$. An iron-mimicking, Trojan horse-entering fungi--has the time come for molecular imaging of fungal infections? PLoS Pathog. 2015;11(1):e1004568.

27. Ankrah AO, Sathekge MM, Dierckx RA, Glaudemans AW. Imaging fungal infections in children. Clin Transl Imaging. doi:10.1007/s40336-015-0159-2.

28. Vallabhaneni S, Mody RK, Walker T, Chiller T. The Global Burden of Fungal Diseases. Infect Dis Clin North Am. 2015; pii: S0891-5520(15)00093-8.

29. Anesi JA, Baddley JW. Approach to the Solid Organ Transplant Patient with Suspected Fungal Infection. Infect Dis Clin North Am. 2015; pii: S0891-5520(15)00090-2.

30. Kullberg BJ, Arendrup MC. Invasive Candidiasis. N Engl J Med. 2015; 373(15):1445-56.

31. Kosmidis C, Denning DW (2015) Republished: The clinical spectrum of pulmonary aspergillosis. Postgrad Med J. 2015;91(1077):403-10.

32. Ozsevik SN, Sensoy G, Karli A, Albayrak C, Dagdemir A, Belet $\mathrm{N}$ et al. Invasive fungal infections in children with hematologic and malignant diseases. J Pediatr Hematol Oncol. 2015;37(2):e69-72

33. Klingspor L, Saaedi B, Ljungman P Szakos A. Epidemiology and outcomes of patients with invasive mould infections: a retrospective observational study from a single centre (20052009). Mycoses. 2015;58(8):470-7.

34. De Pascale G, Tumbarello M. Fungal infections in the ICU: advances in treatment and diagnosis. Curr Opin Crit Care. 2015;21(5):421-9.

35. McCarty TP, Pappas PG. Invasive Candidiasis. Infect Dis Clin North Am. 2015; pii: S08915520(15)00114-2.

36. Lai CC, Tan CK, Huang YT, Shao PL, Hsueh PR. Current challenges in the management of invasive fungal infections. J Infect Chemother. 2008;14(2):77-85.

37. Kelly MS, Benjamin DK Jr, Smith PB. The epidemiology and diagnosis of invasive candidiasis among premature infants. Clin Perinatol. 2015;42(1):105-17.

38. Sanguinetti M, Posteraro B, Lass-Flörl C. Antifungal drug resistance among Candida species: mechanisms and clinical impact. Mycoses. 2015;58 Suppl 2:2-13.

39. De Castro N, Mazoyer E, Porcher R, Raffoux E, Suarez F, Ribaud P et al. Hepatosplenic candidiasis in the era of new antifungal drugs: a study in Paris 2000-2007. Clin Microbiol Infect. 2012;18(6):E185-7.

40. Chen SC, Sorrell TC, Chang CC, Paige EK, Bryant PA, Slavin MA. Consensus guidelines for the treatment of yeast infections in the haematology, oncology and intensive care setting, 2014. Intern Med J. 2014;44(12b):1315-32. 
41. Oude Lashof AM, Donnelly JP, Meis JF, van der Meer JW, Kullberg BJ. Duration of antifungal treatment and development of delayed complications in patients with candidaemia. Eur J Clin Microbiol Infect Dis 2003; 22: 43-48.

42. Blyth CC, Gilroy NM, Guy SD, Chambers ST, Cheong EY, Gottlieb T et al. Consensus guidelines for the treatment of invasive mould infections in haematological malignancy and haemopoietic stem cell transplantation, 2014. Intern Med J. 2014; 44(12b):1333-49.

43. Walsh TJ, Anaissie EJ, Denning DW, Herbrecht R, Kontoyiannis DP, Marr KA et al. Treatment of aspergillosis: clinical practice guidelines of the Infectious Diseases Society of America. Clin Infect Dis 2008;46:327-360.

44. Park BJ, Wannemuehler KA, Marston BJ, Govender N, Pappas PG, Chiller TM.Estimation of the current global burden of cryptococcal meningitis among persons living with HIV/AIDS. AIDS. 2009;23(4):525-30.

45. Cortez KJ, Roilides E, Quiroz-Telles F, Meletiadis J, Antachopoulos C, Knudsen T et al. Infections caused by Scedosporium spp. Clin Microbiol Rev 2008; 21:157-97.

46. Troke P, Aguirrebengoa K, Arteaga C, Ellis D, Heath CH, Lutsar I et al. Treatment of scedosporiosis with voriconazole: clinical experience with 107 recipients. Antimicrob Agents Chemother 2008;52: 1743-1750.

47. Igai $H$, Gotoh $M$, Yokomise H. Computed tomography (CT) and positron emission tomography with [18F]fluoro-2-deoxy-D-glucose (FDG-PET) images of pulmonary cryptococcosis mimicking lung cancer. Eur J Cardiothorac Surg. 2006;30(6):837-9.

48. Salhab KF, Baram D, Bilfinger TV. Growing PET positive nodule in a patient with histoplasmosis: case report. J Cardiothorac Surg. $2006 ; 1: 23$.

49. Ahn BC, Lee SW, Lee J, Kim C. Pulmonary aspergilloma mimicking metastasis from papillary thyroid cancer. Thyroid. 2011;21(5):555-8.

50. Bleeker-Rovers CP, Vos FJ, Wanten GJ, van der Meer JW, Corstens FH, Kullberg BJ, Oyen WJ. 18F-FDG PET in detecting metastatic infectious disease. 2005;J Nucl Med 46(12):2014-9.

51. Wang J, Ju HZ, Yang MF. Pulmonary cryptococcosis and cryptococcal osteomyelitis mimicking primary and metastatic lung cancer in (18)F-FDG PET/CT. Int J Infect Dis. 2014;18:101-3.

52. Cortegiani A, Russotto V, Maggiore A, Attanasio M, Naro AR, Raineri SM, Giarratano A. Antifungal agents for preventing fungal infections in non-neutropenic critically ill patients. Cochrane Database Syst Rev. 2016;1:CD004920.

53. Bassetti M, Marchetti M, Chakrabarti A, Colizza S, Garnacho-Montero J, Kett DH, et al. A research agenda on the management of intra-abdominal candidiasis: results from a consensus of multinational experts. Intensive Care Medicine 2013;39(12):2092-106.

54. Cuenca-Estrella M, Verweij PE, Arendrup MC, Arikan-Akdagli S, Bille J, Donnelly JP, et al. ESCMID guideline for the diagnosis and management of Candida diseases 2012: diagnostic procedures. Clinical Microbiology and Infection 2012;18(Suppl 7):9-18.

55. Fernandez J, Erstad BL, Petty W, Nix DE. Time to positive culture and identification for Candida blood stream infections. Diagnostic Microbiology and Infectious Disease 2009;64(4):402-7.

56. Garey KW, Rege M, Pai MP, Mingo DE, Suda KJ, Turpin RS, et al. Time to initiation of fluconazole therapy impacts mortality in patients with candidemia: a multi-institutional study. Clinical Infectious Diseases 2006;43(1):25-31. 
57. Kollef M, Micek S, Hampton N, Doherty JA, Kumar A. Septic shock attributed to Candida infection: importance of empiric therapy and source control. Clinical Infectious Diseases 2012;54(12):1740-6.

58. Matthew M, Fraser VJ, Kollef MH. Delaying the empiric treatment of Candida bloodstream infection until positive blood culture results are obtained: a potential risk factor for hospital mortality. Antimicrobial Agents and Chemotherapy 2005;49(9):3640-5.

59. Puig-Asensio M, Padilla B, Garnacho-Montero J, Zaragoza O, Aguado JM, Zaragoza R, et al. Epidemiology and predictive factors for early and late mortality in Candida bloodstream infections: a population-based surveillance in Spain. Clinical Microbiology and Infection 2014;20(4):0245-54.

60. Cornely OA, Bassetti M, Calandra T, Garbino J, Kullberg BJ, Lortholary O. ESCMID guideline for the diagnosis and management of Candida diseases 2012: non-neutropenic adult patients. Clinical Microbiology and Infection 2012;18 Suppl 7:19-37.

61. Mikulska M, Calandra T, Sanguinetti M, Poulain D, Viscoli C, the Third European Conference on Infections in Leukemia Group. The use of mannan antigen and anti-mannan antibodies in the diagnosis of invasive candidiasis: recommendations from the Third European Conference on Infections in Leukemia. Critical Care 2010;14:R222.

62. Posteraro B, De Pascale G, Tumbarello M, Torelli R, Pennisi MA, Bello G, et al. Early diagnosis of candidemia in intensive care unit patients with sepsis: a prospective comparison of (1-3)-bD-glucan assay, Candida score, and colonization index. Critical Care 2011;15:R249.

63. Vandeputte $P$, Ferrari S, Coste AT. Antifungal resistance and new strategies to control fungal infections. Int J Microbiol. 2012;2012:713687.

64. Vermes A, Guchelaar HJ, Dankert J. Flucytosine: a review of its pharmacology, clinical indications, pharmacokinetics, toxicity and drug interactions. J Antimicrob Chemother. 2000;46(2):171-9.

65. Stiller RL, Bennett JE, Scholer HJ, Wall M, Polak A, Stevens DA. Correlation of in vitro susceptibility test results with in vivo response: flucytosine therapy in a systemic candidiasis model. J Infect Dis. 1983;147(6):1070-7.

66. Ellis D. Amphotericin B: spectrum and resistance. J Antimicrob Chemother. 2002;49 Suppl 1:710.

67. Albengres $E$, Le Louët $H$, Tillement JP. Systemic antifungal agents. Drug interactions of clinical significance. Drug Saf. 1998;18(2):83-97.

68. Chiou CC, Groll AH, Walsh TJ. New drugs and novel targets for treatment of invasive fungal infections in patients with cancer. Oncologist. 2000;5(2):120-35.

69. Denning DW, Venkateswarlu K, Oakley KL, Anderson MJ, Manning NJ.Itraconazole resistance in Aspergillus fumigatus. Antimicrob Agents Chemother. 1997;41(6):1364-8.

70. Denning DW. Echinocandins: a new class of antifungal. J Antimicrob Chemother. 2002;49(6):889-91.

71. Feldmesser M, Kress Y, Mednick A, Casadevall A. The effect of the echinocandin analogue caspofungin on cell wall glucan synthesis by Cryptococcus neoformans. J Infect Dis. 2000;182(6):1791-5.

72. Cappelletty D, Eiselstein-McKitrick K. The echinocandins. Pharmacotherapy. 2007;27(3):36988. 
73. Blankenship JR, Steinbach WJ, Perfect JR, Heitman J. Teaching old drugs new tricks: reincarnating immunosuppressants as antifungal drugs. Curr Opin Investig Drugs. 2003;4:192-9.

74. Cowen LE, Singh SD, Kohler JR, Collins C, Zaas AK, et al. Harnessing Hsp90 function as a powerful, broadly effective therapeutic strategy for fungal infectious disease. Proc Natl Acad Sci U S A. 2009;106:2818-23.

75. Zhai B, Wu C, Wang L, Sachs MS, Lin X. The antidepressant sertraline provides a promising therapeutic option for neurotropic cryptococcal infections. Antimicrob Agents Chemother . 2012;56: 3758-66.

76. Pikman R, Ben-Ami R. Immune modulators as adjuncts for the prevention and treatment of invasive fungal infections. Immunotherapy. 2012;4(12):1869-82.

77. Price TH, Bowden RA, Boeckh M, Bux J, Nelson K, Liles WC, Dale DC. Phase I/II trial of neutrophil transfusions from donors stimulated with G-CSF and dexamethasone for treatment of patients with infections in hematopoietic stem cell transplantation. Blood. 2000;95(11):3302-9.

78. Pachl J, Svoboda P, Jacobs F, Vandewoude K, van der Hoven B, Spronk P et al. A randomized, blinded, multicenter trial of lipid-associated amphotericin $B$ alone versus in combination with an antibody-based inhibitor of heat shock protein 90 in patients with invasive candidiasis. Clin Infect Dis. 2006;42(10):1404-13.

79. Schmidt S, Tramsen L, Hanisch M, Latgé JP, Huenecke S, Koehl Uet al.

80. Human natural killer cells exhibit direct activity against Aspergillus fumigatus hyphae, but not against resting conidia. J Infect Dis. 2011;203(3):430-5.

81. Safdar A, Rodriguez G, Zuniga J, Al Akhrass F, Georgescu G, Pande A. Granulocyte macrophage colony-stimulating factor in 66 patients with myeloid or lymphoid neoplasms and recipients of hematopoietic stem cell transplantation with invasive fungal disease. Acta Haematol. 2013;129(1):26-34.

82. Franzius $C$, Biermann M, Hülskamp G, Frosch M, Roth J, Sciuk J et al. Therapy monitoring in aspergillosis using F-18 FDG positron emission tomography. Clin Nucl Med 2001; 26(3):232-3.

83. Ozsahin H, von Planta M, Müller I, Steinert HC, Nadal D, Lauener R, et al. Successful treatment of invasive aspergillosis in chronic granulomatous disease by bone marrow transplantation, granulocyte colony-stimulating factor-mobilized granulocytes, and liposomal amphotericin-B. Blood 1998; 92:2719-24.

84. Chamilos G, Macapinlac HA, Kontoyiannis DP. The use of 18F-fluorodeoxyglucose positron emission tomography for the diagnosis and management of invasive mould infections. Med Mycol. 2008; 46(1):23-9.

85. Hot A, Maunoury C, Poiree S, Lanternier F, Viard JP, Loulergue P, et al. Diagnostic contribution of positron emission tomography with [18F]fluorodeoxyglucose for invasive fungal infections. Clin Microbiol Infect 2011; 17(3):409-17.

86. Xu B, Shi P, Wu H, Guo X, Wang Q, Zhou S. Utility of FDG PET/CT in guiding antifungal therapy in acute leukemia patients with chronic disseminated candidiasis. Clin Nucl Med 2010; 35(8):567-70.

87. Avet J Jr, Granjon D, Prevot-Bitot N, Isnardi V, Berger C, Stephan JL, et al. Monitoring of systemic candidiasis by 18F-FDG PET/CT. Eur J Nucl Med Mol Imaging 2009; 36(11):1900. 
88. Wallner M, Steyer G, Krause R, Gstettner C, von Lewinski D. Fungal endocarditis of a bioprosthetic aortic valve. Pharmacological treatment of a Candida parapsilosis endocarditis. Herz 2013; 38(4):431-4.

89. Teyton $P$, Baillet $G$, Hindié E, Filmont JE, Sarandi F, Toubert ME et al. Hepatosplenic candidiasis imaged with F-18 FDG PET/CT. Clin Nucl Med 2009; 34(7):439-40.

90. Ritz N, Ammann RA, Aebischer CC, et al. Failure of voriconazole to cure disseminated zygomycosis in an immunocompromised child. Eur J Pediatr 2005; 164:231-5.

91. Altini C, Niccoli Asabella A, Ferrari C, Rubini D, Dicuonzo F, Rubini G. (18)F-FDG PET/CT contribution to diagnosis and treatment response of rhino-orbital-cerebral mucormycosis. Hell J Nucl Med. 2015;18(1):68-70.

92. Liu Y, Wu H, Huang F, Fan Z, Xu B. Utility of 18F-FDG PET/CT in diagnosis and management of mucormycosis. Clin Nucl Med 2013; 38(9):e370-1.

93. Miyazaki Y, Nawa Y, Nakase K, Kohashi S, Kadohisa S, Hiraoka A et al. FDG-PET can evaluate the treatment for fungal liver abscess much earlier than other imagings. Ann Hematol 2011: 90(12):1489-90.

94. Kasaliwal R, Malhotra G, Bukan A, Asopa RV, Wanjare S, Shah NS. 18F-FDG PET as a monitoring tool to assess treatment response in bilateral adrenal histoplasmosis. Clin Nucl Med. 2014;39(6):576-8.

95. Tsai YJ, Lin YH, Hsu CH, Yeh SD. 18F-fluorodeoxyglucose positron emission tomography for the initial evaluation and monitoring of therapeutic response in bilateral adrenal histoplasmosis. Clin Imaging 2013; 37(4):791-3.

96. Dubbioso R, Pappatà S, Quarantelli M, D'Arco F, Manganelli F, Esposito M, Santoro L. Atypical clinical and radiological presentation of cryptococcal choroid plexitis in an immunocompetent woman. J Neurol Sci. 2013;334(1-2):180-2.

97. Vos FJ, Bleeker-Rovers CP, Oyen WJ. The use of FDG-PET/CT in patients with febrile neutropenia. Semin Nucl Med. 2003;43(5):340-8.

98. Vos FJ, Donnelly JP, Oyen WJ, Kullberg BJ, Bleeker-Rovers CP, Blijlevens NM. 18F-FDG PET/CT for diagnosing infectious complications in patients with severe neutropenia after intensive chemotherapy for haematological malignancy or stem cell transplantation. Eur J Nucl Med Mol Imaging 2012:39:120-8.

99. Ashbee HR, Barnes RA, Johnson EM, Richardson MD, Gorton R, Hope HW Therapeutic drug monitoring (TDM) of antifungal agents: guidelines from the British Society for Medical Mycology. J Antimicrob Chemother. 2014 May; 69(5): 1162-1176.

100. Kang HM, Lee HJ, Cho EY, Yu KS, Lee H, Lee JW, Kang HJ, Park KD, Shin HY, Choi EH. The Clinical Significance of Voriconazole Therapeutic Drug Monitoring in Children With Invasive Fungal Infections. Pediatr Hematol Oncol. 2015;32(8):557-67.

101. Karthaus M, Lehrnbecher T, Lipp HP, Kluge S, Buchheidt D. Therapeutic drug monitoring in the treatment of invasive aspergillosis with voriconazole in cancer patients--an evidencebased approach. Ann Hematol. 2015;94(4):547-56.

102. Huang B, Law MW, Khong PL. Whole-body PET/CT scanning: estimation of radiation dose and cancer risk. Radiology. 2009;251(1):166-74.

103. Rolle AM, Hasenberg M, Thornton CR, Solouk-Saran D, Mann L, Maurer A, et al. ImmunoPET/MR imaging allows specific detection of Aspergillus fumigatus lung infection in vivo. Proc Nat Acad Sci USA. 2016;pii:201518836 